\title{
防波堤捨石マウンド内の津波浸透流に対する 腹付工の効果検討
}

\author{
佐藤 昌宏 1 ・大村 厚夫 1 柴田 大介 ${ }^{2}$ ・上原 甲太郎 2 ・及川隆 3 ・青木 伸之 ${ }^{3}$ \\ 1正会員 一般財団法人沿岸技術研究センター（†105-0003 東京都港区西新橋一丁目14-2） \\ E-mail:m_satou@cdit.or.jp
}

2正会員 株式会社日本港湾コンサルタント 技術本部（†141-0031 東京都品川区西五反田八丁目3-6）

3 国土交通省仙台港湾空港技術調查事務所（干983-0852 仙台市宮城野区榴岡五丁目 1-35）

\begin{abstract}
ケーソン式防波堤に津波が来襲する場合，津波による防波堤の内外水位差に伴い，基礎捨石マウンドに は浸透流が発生し，支持力が低下寸る。この現象を定量的に把握するために，地盤解析汎用プログラム $\lceil$ GeoFem」の適用性を検討するとともに, 腹付工による支持力増加効果を計算した。 また，浸透力の有 無を考慮可能なGeoFemによる適用結果と，浸透力の影響を考慮していない簡易ビショップ法を用いた円 弧すべり解析結果を比較した。本検討では，GeoFemによる浸透力の効果を簡易ビショップ法での耐力作 用比の低下と捉えて，簡易ビショップ法を用いて浸透力の効果を見込んだ耐力照査を行うこととし，簡易 ビショップ法とGeoFemで求めた耐力作用比を比較した結果, 高い相関性がみられた。これにより, 簡易 ビショップ法の結果に安全率を乗じることで，浸透力を踏まえた検討の可能性が示唆された．
\end{abstract}

Key Words : tsunami,breakwater,seepage,simplified Bishop method, finite element analysis

\section{1. はじめに}

防波堤の支持力破壊に及ぼすマウンド内の浸透力の影 響について定量的に検討した．本検討では，ケーソンの 背後を抑える効果を期待した腹付工4断面について比較 し，支持力向上に対して優位性の高い形状の検討を行っ た. 波力の算定には，背後水位の上昇を考慮した波圧分 布算定式を用いた．検討水位は3ケースを設定し，水位 による影響を把握した．基礎の支持力照査は，「簡易ビ ショップ法」 ${ }^{1)}$ と， (国研) 港湾空港技術研究所らが開 発したマウンド内の浸透力の考慮可能な「GeoFem」23) の両者を用いた，GeoFemでは，限界水平荷重と検討水 位時の水平荷重（津波波力）の比を耐力作用比と定義） して評価した．さらに，簡易ビショップ法とGeoFemに より求めた「而力作用比」の相関性を確認した.

\section{2. 検討内容}

\section{(1) 検討断面}

a)基本断面の設定

本検討では腹付工による支持力向上効果の確認を行 うため，基本断面として発生頻度の高い津波に対して滑 動・転倒よりも支持力の破壊モードが卓越する大船渡湾
口防波堤の標準断面を選定した．図-1に基本断面を示寸． b)対策断面の設定

対策断面は，腹付工の高さと法面増厚の効果確認を踏 まえて4断面設定した．図-2に，腹付工設置箇所別の対 策断面を示寸.

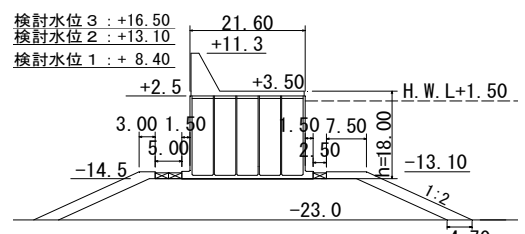

図-1 Case1 基本断面

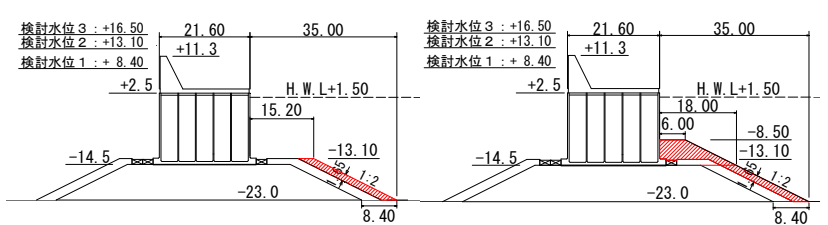

Case2 腹付なし

(マウンド拡張)

Case3 腹付高 $1 / 3$

(法面増厚)

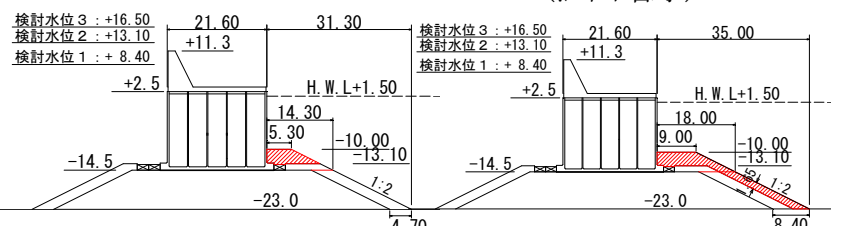

Case4 腹付高 $1 / 4$

Case5 腹付高 $1 / 4$

(法面増厚)

図-2 腹付工設置箇所別の対策断面 
腹付工の天端高は, 図-1に示すケーソン壁高 $(h=18.0 \mathrm{~m})$ の1/3 (D.L.-8.5m) , 1/4（D.L.-10.0m）とした. また，法面厚は，増厚するケースは全て $1.65 \mathrm{~m}$ と同一に した，腹付工高さの効果は，腹付なし，腹付高 $1 / 4$, 腹 付高1/3の3ケースを比較した（Case2,Case5,Case3）。また, 法面増厚の効果は，基本断面とその基礎捨石マウンド拡 張の2ケース（Case1,Case2）および，腹付高1/4で法面増 厚の2ケース（Case4,Case5）をそれぞれ比較した.

c)検討水位および防波堤に作用する波圧の算定

支持力の安定性を照査する検討水位は，その影響を把 握するために3ケースを設定した. 港内側水位を塑望平均 満潮位のD.L.+1.50mとし，3ケースともに同一とした. 港外側水位を越流しない条件として，「検討水位1」は 発生頻度の高い津波相当のD.L.+8.40m（港内側水位との 差6.9m），越流する条件として，「検討水位2」は最大 クラスの津波相当のD.L.+13.10m（港内側水位との差 $11.6 \mathrm{~m})$ ，「検討水位3」は最大クラスの津波を超える D.L.+16.50m（港内側水位との差15.0m）に設定した.

防波堤に作用する波圧の算定では，背後水位の上昇を 考慮した波圧分布算定式を用いた（式(1)〜式(3)） 5). 図-

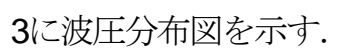

$\bigcirc$ 前面波力 $P_{\mathrm{I}}$ の算定 (非越流時は $\left.p_{2}=0\right)$

$$
\begin{aligned}
P_{\mathrm{I}} & =1 / 2\left(p_{1}+p_{2}\right)\left(h^{\prime}+h \mathrm{c}^{*}\right) \\
p_{1} & =\rho_{0} g\left(h^{\prime}+\eta\right) \times \alpha_{\mathrm{I}} \\
p_{2} & =\left(\eta-h \mathrm{c}^{*}\right) /\left(h^{\prime}+\eta\right) p_{1} \\
h \mathrm{c}^{*} & =\min (\eta, h \mathrm{c})
\end{aligned}
$$

$$
\begin{aligned}
& P_{\mathrm{B}}=1 / 2\left(p_{3}+p_{4}\right)\left(h^{\prime}+h \mathrm{c}_{\mathrm{B}}{ }^{*}\right) \\
& p_{3}=\rho_{0} g\left(h^{\prime}+\eta_{\mathrm{B}}\right) \times \alpha_{\mathrm{B}} \\
& p_{4}=\left(\eta_{\mathrm{B}}-h \mathrm{c}_{\mathrm{B}}{ }^{*}\right) /\left(h^{\prime}+\eta_{\mathrm{B}}\right) p_{3} \\
& h \mathrm{c}_{\mathrm{B}}{ }^{*}=\min \left(\eta_{\mathrm{B}}, h \mathrm{c}\right)
\end{aligned}
$$

$\bigcirc$ 揚圧力合力 $P_{U}$ の算定（浮力、揚力を含む）

$$
\begin{aligned}
P_{U} & =1 / 2\left(p_{1}+p_{3}\right) B-1 / 2\left(p_{2}+p_{4}\right) B \\
& \text { ここで、 }
\end{aligned}
$$

$\eta:$ : 静水面上の前面の津波高さ(m)

$\eta_{\mathrm{B}}:$ 静水面上の背面の津波高さ $(\mathrm{m})$

$h^{\prime}$ : 堤体の前面における水深(m)

$\rho_{0} g:$ 海水の単位体積重量 $\left(\mathrm{kN} / \mathrm{m}^{3}\right)$

$p_{1} \quad$ : 堤体下端部における前面波圧強度 $\left(\mathrm{kN} / \mathrm{m}^{2}\right)$

$p_{2}$ : 堤体上端部における前面波圧強度 $\left(\mathrm{kN} / \mathrm{m}^{2}\right)$

$p_{3}:$ 堤体下端部における背面波圧強度 $\left(\mathrm{kN} / \mathrm{m}^{2}\right)$

$p_{4}$ : 堤体上端部における背面波圧強度 $\left(\mathrm{kN} / \mathrm{m}^{2}\right)$

$B$ : 堤体幅 $(\mathrm{m})$

当式は，防波堤前後の波圧分布を静水圧分布形と仮定 している．また，堤体上面と下面に作用する圧力を直接
評価することで，浮力及び越流時に流れの作用によって 生じる揚力は，揚圧力合力Pu として一体として評価で きることが特徵である.

なお, 静水圧に対する変動率（静水圧補正係数）は, 防波堤前面の波圧に対して $\alpha_{\mathrm{I}}=1.05$, 背後圧は $\alpha_{\mathrm{B}}=0.90$ とした6.

\section{（2） 津波浸透流を考慮した基礎の支持力照査方法}

\section{a) 地盤解析汎用プログラム「GeoFem」}

図-4に，GeoFemを用いた基礎の支持力照査フローを 示す. GeoFem は仮想的な弾・粘塑性アルゴリズムに基 づく計算法（仮想粘性法）を導入し，地盤など一部要素 が破壊状態に近い条件であっても安定的に計算を行える 特徴を有している2). GeoFemは，津波水位差によりマウ ンド内に発生する浸透力の考慮が可能である ${ }^{3)}$. 浸透力 の算出は，浸透流解析によりマウンドの各要素の積分点 に作用する浸透力 $\left(F=i \cdot \gamma_{w}\right)$ を求めて, 応力変形解析 時に浸透力をマウンドの各要素の積分点に付加させてい る. なお，浸透流の平均流速（v） と動水勾配（i）の関 係にはダルシー則を用いた。

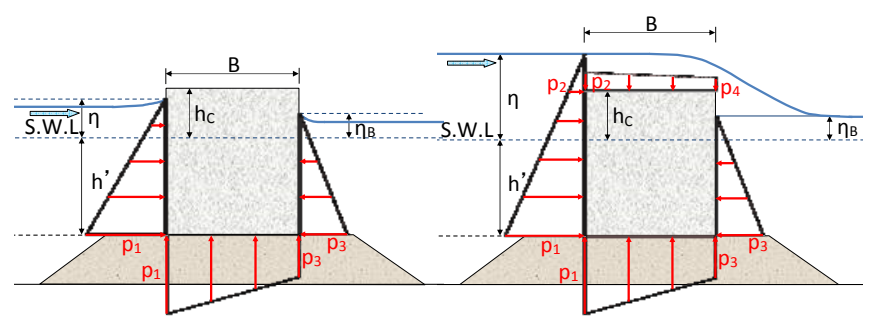

(a) 非越流時

(b) 越流時

図-3 波圧分布図 ${ }^{5}$

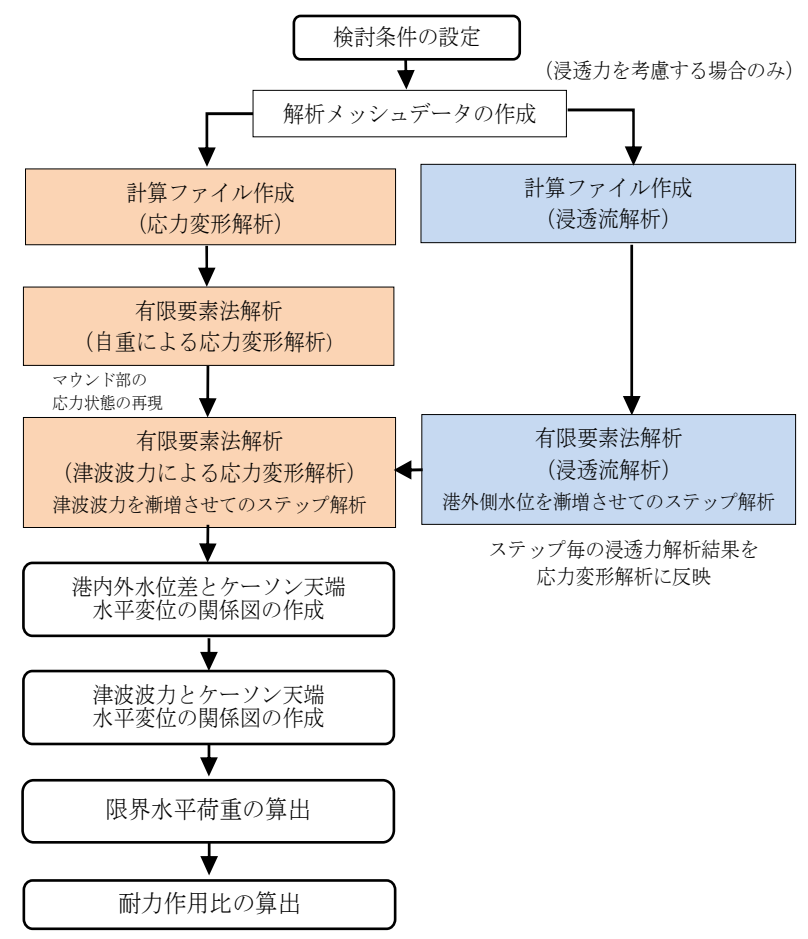

図-4 GeoFemを用いた基礎の支持力照査フロー 
GeoFemでは，浸透流解析と応力変形解析を2段階で実 施する.まず，検討断面の解析メッシュデータを作成し， 第一段階では，浸透流解析を行う際の計算ファイルを作 成する. ここで，マウンド内の浸透力は，水頭差によっ て発生することからマウンドに作用する水頭 $H_{1}(\mathrm{~m})$ を設 定する．水頭の設定では，港内側の水位は変動しない一 定值（H.W.L.+1.50m） として水頭0.0mを与える. 一方,

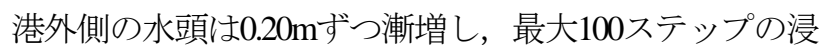
透流解析を行う.

第二段階では，応力変形解析を行う際の計算ファイル を作成する．計算ファイルは，津波波力式により算定し た水平力と揚圧力を水位差毎にケーソンへ作用させる. ステップ1では自重解析による要素内の初期応力計算を 行う. ステップ2では初期水圧（水頭差 $0.0 \mathrm{~m} ）$ を作用さ せ，ステップ3〜102では水平力と揚圧力を漸増させた応 力変形解析を行う。図-5に，津波波力による分布荷重の 設定イメージを示す. なお，各解析ステップでは，先に 求めた浸透力を加味して計算している.

b) 限界水平荷重および耐力作用比の算定方法

本検討では，浸透力による支持力低下現象の影響度合 いを比較するため，「浸透力を考慮しない場合」と「浸 透力を考慮する場合」の両ケースについて解析を実施し た．前述のGeoFemの計算結果を用いて，ステップ毎の 「港内外水位差とケーソン天端水平変位の関係（水位差 変位図）」，「水平力（津波波力）とケーソン天端水平 変位の関係（荷重変位図）」を作成し，浸透力による影 響を確認した. 図-6にCase1 基本断面の水位差変位図, 図-7に荷重変位困を示す。水位差変位図では，水位差が 大きくなるにつれてケーソン天端変位が大きくなり，浸 透力を考慮しない場合は水位差 $11.2 \mathrm{~m}$ ，浸透力を考慮す る場合は水位差 $10.4 \mathrm{~m}$ で破壊に至る結果となった。一方， 荷重変位図では，荷重変位曲線の変曲点を過ぎて変位が 無限大となったため, 破壊直前で通常のステップ解析が 可能な荷重を「限界水平荷重」と定義した.

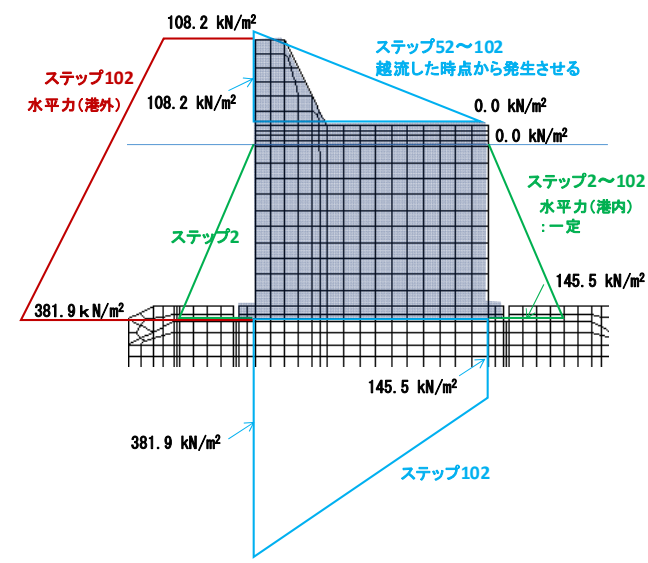

図-5 津波波力による分布荷重の設定（応力変形解析）
GeoFemを用いた基礎の支持力照査は，簡易ビショッ プ法と異なり直接的に耐力作用比を求めることができな いため，ここで定義した限界水平荷重と港内外水位差毎 の水平荷重（津波波力）の比を「耐力作用比」と定義し て評価した。

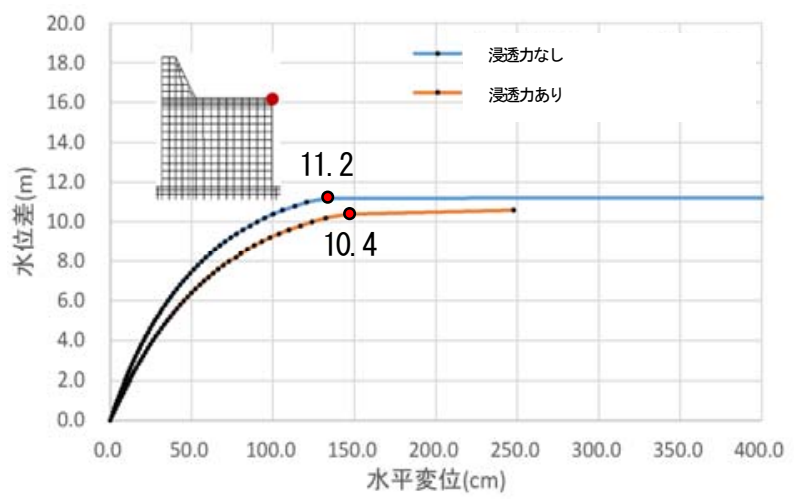

図-6 水位差変位図（Case1 基本断面）

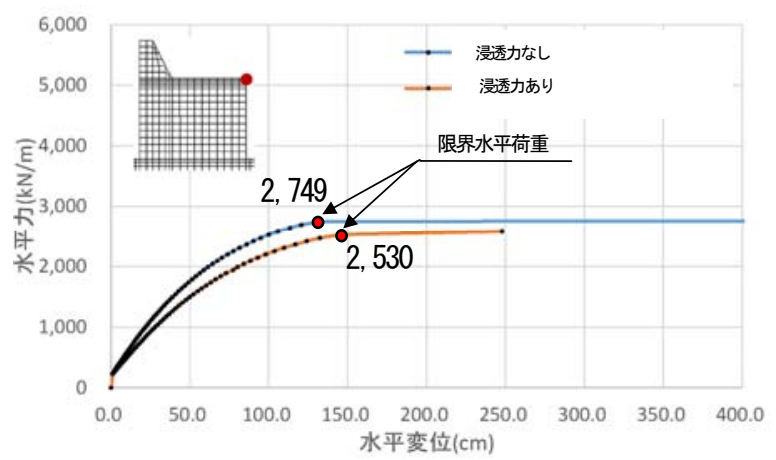

図-7 荷重変位図（Case1 基本断面）

c) 解析モデルの設定

図-8にCase1基本断面の解析モデル，表-1に解析に用い た物性值を示す.

原地盤の砂質土層（ $N=10 ）$ の変形係数は, GeoFemマ ニュアル7に準じて $E=6 N+10\left(\mathrm{kgf} / \mathrm{cm}^{2}\right)$ (日本道路協会 $)^{8)}$ を用いて設定した．また，透水係数は，港湾基準 ${ }^{9}$ に準 じて砂層の透水係数概略值 $10^{-2} \mathrm{~cm} / \mathrm{s}$ した.

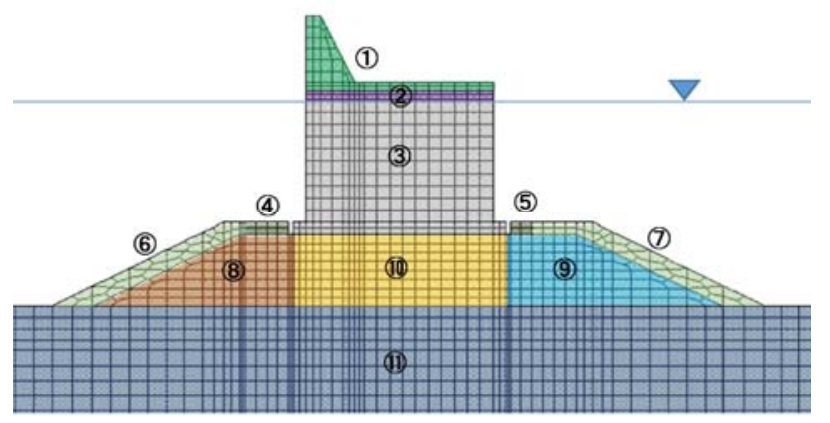

図-8 解析モデル (Case1 基本断面) 
図-9に拘束圧の違いによる $c, \phi\left(\right.$ 関係 $^{10)}$ を示す。拘束 圧の大きいケーソン直下および港外側マウンドのc, 図中のLine(2), 拘束圧の小さい港内側マウンドの $c, \phi$ は困 中のLine(1)を参考に設定した。なお，ケーソン下部の摩 擦増大マットはモデル化していない.

\section{3. 検討結果}

\section{（1）津波浸透流の影響と腹付工の効果}

表-2に検討結果の一覧を示す。津波浸透力の影響は， 耐力作用比低減率（=浸透力ありの耐力作用比 $\div$ 浸透力 なしの耐力作用比）より，浸透流を考慮した場合には， 考慮しない場合と比較して，耐力作用比が6〜 10\%低下 する結果となった，長野らの文献)では，GeoFemを用い た釜石港の防波堤をモデルにした照査では，耐力作用比

表-1 解析モデルの物性値（Case1 基本断面）

\begin{tabular}{|c|c|c|c|c|c|c|c|}
\hline \multirow[t]{2}{*}{ No } & \multirow[t]{2}{*}{ 地層区分 } & \multirow[t]{2}{*}{ 構成則 } & $\begin{array}{c}\text { 土質試験の } \\
\text { 粘着力 }\end{array}$ & $\begin{array}{l}\text { せん断 } \\
\text { 抵抗角 }\end{array}$ & 変形係数 & $\begin{array}{l}\text { ポアソン } \\
\text { 比 }\end{array}$ & 透水係数 \\
\hline & & & $\mathrm{c}\left(\mathrm{KN} / \mathrm{m}^{2}\right)$ & $\varphi$ (度) & $\mathrm{E}\left(\mathrm{MN} / \mathrm{m}^{2}\right)$ & $v$ & $\mathrm{k}(\mathrm{m} / \mathrm{s})$ \\
\hline 1 & 上部コンクリート & 線形弾性体 & - & - & $1.00 \mathrm{E}+05$ & 0.17 & 0.0 \\
\hline $\begin{array}{l}2 \\
3\end{array}$ & ケーソン & 線形弾性体 & - & - & $1.00 \mathrm{E}+05$ & 0.17 & 0 \\
\hline $\begin{array}{l}4 \\
5\end{array}$ & 根固ブロック & $\begin{array}{l}\text { Mohr-Coulomb } \\
\text { 弾塑性 }\end{array}$ & - & - & $1.00 \mathrm{E}+05$ & 0.17 & $1.00 \mathrm{E}-09$ \\
\hline $\begin{array}{l}6 \\
7\end{array}$ & 被覆石 & $\begin{array}{l}\text { Mohr-Coulomb } \\
\text { 弾塑性 }\end{array}$ & 20.00 & 35 & 30 & 0.33 & 0.2 \\
\hline 8 & $\begin{array}{l}\text { マウンド } \\
\text { (港外側) }\end{array}$ & $\begin{array}{l}\text { Mohr-Coulomb } \\
\text { 弾塑性 }\end{array}$ & 20.00 & 35 & 30 & 0.33 & 0.2 \\
\hline 9 & $\begin{array}{l}\text { マウンド } \\
\text { (港内側) }\end{array}$ & $\begin{array}{l}\text { Mohr-Coulomb } \\
\text { 弾塑性 }\end{array}$ & 5.00 & 40 & 30 & 0.33 & 0.2 \\
\hline 10 & $\begin{array}{c}\text { マウンド } \\
\text { (ケーソン直下) }\end{array}$ & $\begin{array}{l}\text { Mohr-Coulomb } \\
\text { 弾塑性 }\end{array}$ & 20.00 & 35 & 30 & 0.33 & 0.2 \\
\hline 11 & 砂質土層 & 線形弾性体 & - & 30 & 7 & 0.33 & $1.00 \mathrm{E}-04$ \\
\hline
\end{tabular}

が6〜9\%低下することが述べられている，また，高橋ら の文献 ${ }^{3)}$ では，水理模型実験より，港内外の水位差が8.3 〜9.3m程度の場合には浸透力が支持力を $10 １ 6 \%$ 低減す ることが述べられている. 本検討結果は既往のこれらの 研究成果とも調和的であり，浸透力による支持力の低下 は，1割〜2割程度を見込む必要があることを定量的に把 握できた.

腹付工の形状の違いによる支持力への影響については， まず，腹付工高さの比較について，GeoFemで求めた耐 力作用比は浸透力なし，浸透力あり共に「Case2 < Case5 <Case3」となり，腹付高さが高いほど支持力向上に対 して効果があることを確認した.

次に, 法面増厚の比較について, 耐力作用比はマウン ド拡張の検討が「Case1<Case2」，腹付高1/4で法面増厚 の検討が「Case4<Case5」となり，法面増厚の効果を確 認した.ケース全体では「Case $1<$ Case $2<$ Case4 $<$ Case5 $<$ Case3」となり，「Case3 腹付高1/3 (法面増厚)」が最 も支持力向上に対して効果がある結果となった.

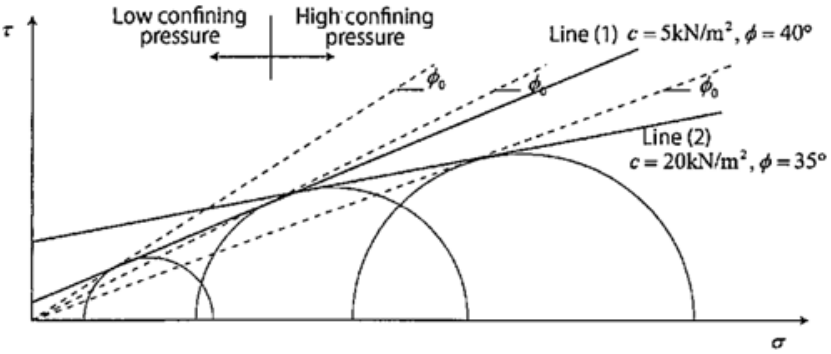

(a) Definition of $\phi_{0}$

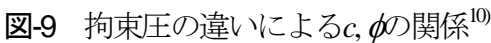

表-2 検討結果一覧

\begin{tabular}{|c|c|c|c|c|c|c|c|c|c|c|c|c|}
\hline \multirow[b]{2}{*}{ 腹付形状 } & \multicolumn{4}{|c|}{ 水位条件 } & 外力 & \multicolumn{6}{|c|}{ GeoFem } & \multirow{2}{*}{$\begin{array}{c}\text { 簡易ビショップ法 } \\
\text { 耐力作用比 }\end{array}$} \\
\hline & & 港外側 & 港内側 & 水位差 & $\begin{array}{c}\text { (1) 津波 } \\
\text { 波力 } \\
(\mathrm{kN} / \mathrm{m})\end{array}$ & $\begin{array}{c}\text { (2)限界 } \\
\text { 水平荷重 } \\
\text { (浸透力なし) }\end{array}$ & $\begin{array}{c}\text { (3)限界 } \\
\text { 水平荷重 } \\
\text { (浸䢪力ありり) }\end{array}$ & $\begin{array}{c}\text { 耐力作用比 } \\
\text { (浸透力なし) } \\
=\text { (2)/1(1) }\end{array}$ & $\begin{array}{l}\text { 而力作用比 } \\
\text { (浸透力ありり) } \\
=\text { (3)/1 }\end{array}$ & $\begin{array}{l}\text { 耐力作用比 } \\
\text { 低減率 } \\
=(3) /(2)\end{array}$ & 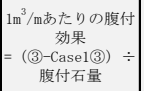 & \\
\hline \multirow{3}{*}{$\begin{array}{c}\text { Case } 1 \\
\text { 基本断面 }\end{array}$} & 水位 1 & D. L. $+8.4 \mathrm{~m}$ & \multirow{3}{*}{ D. L. $+1.5 \mathrm{~m}$} & $6.9 \mathrm{~m}$ & 1,618 & \multirow{3}{*}{2,749} & \multirow{3}{*}{2,530} & $1.70>1.00$ & $1.56>1.00$ & \multirow{3}{*}{0.920} & \multirow{3}{*}{-} & $1.62>1.00$ \\
\hline & 水位 2 & D. L. $+13.1 \mathrm{~m}$ & & $11.6 \mathrm{~m}$ & 2,860 & & & $0.96<1.00$ & $0.88<1.00$ & & & $0.89<1.00$ \\
\hline & 水位 3 & D. L. $+16.5 \mathrm{~m}$ & & $15.0 \mathrm{~m}$ & 3,790 & & & $0.73<1.00$ & $0.67<1.00$ & & & $0.55<1.00$ \\
\hline \multirow{3}{*}{$\begin{array}{c}\text { Case2 } \\
\text { 腹付なし } \\
\text { (マウンド拡張) }\end{array}$} & 水位 1 & D. L. $+8.4 \mathrm{~m}$ & \multirow{3}{*}{ D. L. $+1.5 \mathrm{~m}$} & $6.9 \mathrm{~m}$ & 1,618 & \multirow{3}{*}{2,859} & \multirow{3}{*}{2,585} & $1.77>1.00$ & $1.60>1.00$ & \multirow{3}{*}{0.904} & \multirow{3}{*}{1.5} & $1.73>1.00$ \\
\hline & 水位 2 & D. L. $+13.1 \mathrm{~m}$ & & $11.6 \mathrm{~m}$ & 2,860 & & & $1.00>1.00$ & $0.90<1.00$ & & & $0.96<1.00$ \\
\hline & 水位 3 & D. L. $+16.5 \mathrm{~m}$ & & $15.0 \mathrm{~m}$ & 3,790 & & & $0.75<1.00$ & $0.68<1.00$ & & & $0.61<1.00$ \\
\hline \multirow{3}{*}{$\begin{array}{c}\text { Case3 } \\
\text { 腹付高 } 1 / 3 \\
\text { (法面増厚) }\end{array}$} & 水位 1 & D. L. $+8.4 \mathrm{~m}$ & \multirow{3}{*}{ D. L. $+1.5 \mathrm{~m}$} & $6.9 \mathrm{~m}$ & 1,618 & \multirow{3}{*}{3,351} & \multirow{3}{*}{3,132} & $2.07>1.00$ & $1.94>1.00$ & \multirow{3}{*}{0.935} & \multirow{3}{*}{ 7. 0} & $1.78>1.00$ \\
\hline & 水位 2 & D. L. $+13.1 \mathrm{~m}$ & & $11.6 \mathrm{~m}$ & 2,860 & & & $1.17>1.00$ & $1.10>1.00$ & & & $1.00>1.00$ \\
\hline & 水位 3 & D. L. $+16.5 \mathrm{~m}$ & & $15.0 \mathrm{~m}$ & 3,790 & & & $0.88<1.00$ & $0.83<1.00$ & & & $0.65<1.00$ \\
\hline \multirow{3}{*}{$\begin{array}{c}\text { Case } 4 \\
\text { 腹付高 } 1 / 4\end{array}$} & 水位 1 & D. L. $+8.4 \mathrm{~m}$ & \multirow{3}{*}{ D. L. $+1.5 \mathrm{~m}$} & $6.9 \mathrm{~m}$ & 1,618 & \multirow{3}{*}{3,077} & \multirow{3}{*}{2,859} & $1.90>1.00$ & $1.77>1.00$ & \multirow{3}{*}{0.929} & \multirow{3}{*}{12.5} & $1.65>1.00$ \\
\hline & 水位 2 & D. L. $+13.1 \mathrm{~m}$ & & $11.6 \mathrm{~m}$ & 2,860 & & & $1.08>1.00$ & $0.99<1.00$ & & & $0.91<1.00$ \\
\hline & 水位 3 & D. L. $+16.5 \mathrm{~m}$ & & $15.0 \mathrm{~m}$ & 3,790 & & & $0.81<1.00$ & $0.75<1.00$ & & & $0.57<1.00$ \\
\hline \multirow{3}{*}{$\begin{array}{c}\text { Case5 } \\
\text { 腹付高 } 1 / 4 \\
\text { (法面増厚) }\end{array}$} & 水位 1 & D. L. $+8.4 \mathrm{~m}$ & \multirow{3}{*}{ D. L. $+1.5 \mathrm{~m}$} & $6.9 \mathrm{~m}$ & 1,618 & \multirow{3}{*}{3,296} & \multirow{3}{*}{3,077} & $2.04>1.00$ & $1.90>1.00$ & \multirow{3}{*}{0.934} & \multirow{3}{*}{ 7. 4} & $1.77>1.00$ \\
\hline & 水位 2 & D. L. $+13.1 \mathrm{~m}$ & & $11.6 \mathrm{~m}$ & 2,860 & & & $1.15>1.00$ & $1.08>1.00$ & & & $1.01>1.00$ \\
\hline & 水位 3 & D. L. $+16.5 \mathrm{~m}$ & & $15.0 \mathrm{~m}$ & 3,790 & & & $0.87<1.00$ & $0.81<1.00$ & & & $0.64<1.00$ \\
\hline
\end{tabular}


一方，腹付工 $1 \mathrm{~m}^{3}$ たりの支持力向上効果に着目する と「Case2 $<$ Case3 $<$ Case $<<$ Case4」となった. Case4は腹 付高 $1 / 4$ で法面は増厚していないことから，ケーソン後 趾付近に対策工を設置することが支持力向上に対して最 も効果的であることが確認できた.

次に, 腹付工が支持力向上に寄与寸るメカニズムを把 握するために, GeoFemの応力変形解析結果をもとに腹 付工の有無による垂直応力 $\left(\sigma_{y}\right)$ の違いを確認した。 ここ で, 垂直応力の着目点は, 港内側マウンド部の節点とし た（図-10）。図-11に，着目点における解析ステップ別 の垂直応力 $\left(\sigma_{y}\right)$ を示寸. 腹付工なしのCase1では， $\sigma_{\mathrm{y}}$ は一 定值を示したが，腹付工ありのCase4では，解析ステッ プが進むにつれて右上がりに上昇し，ステップ40を超え て越流が生じると以降は勾配が緩やかになる結果となっ た．これは，津波波力を受けたケーソンにより腹付工が 押され，港内側マウンドを押さえつける方向に荷重が作 用したことによる上昇と考えられる. 寸なわち，腹付工 が抵抗モーメントにも寄与寸ることを示した. 浸透力の 有無で比較した場合, Case4では破壊時に浸透力ありの $\sigma_{\mathrm{y}}$ が2割程度低減することがわかった。

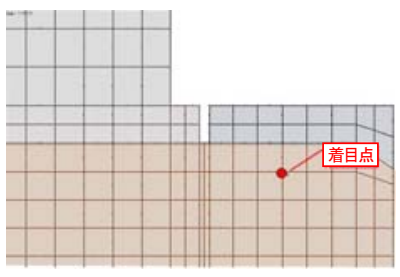

Case1 基本断面

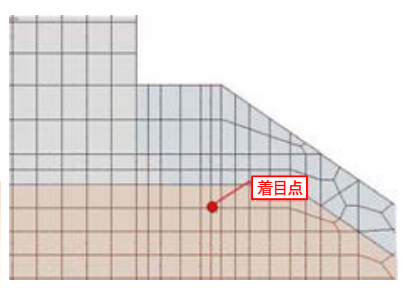

Case4 腹付高 $1 / 4$
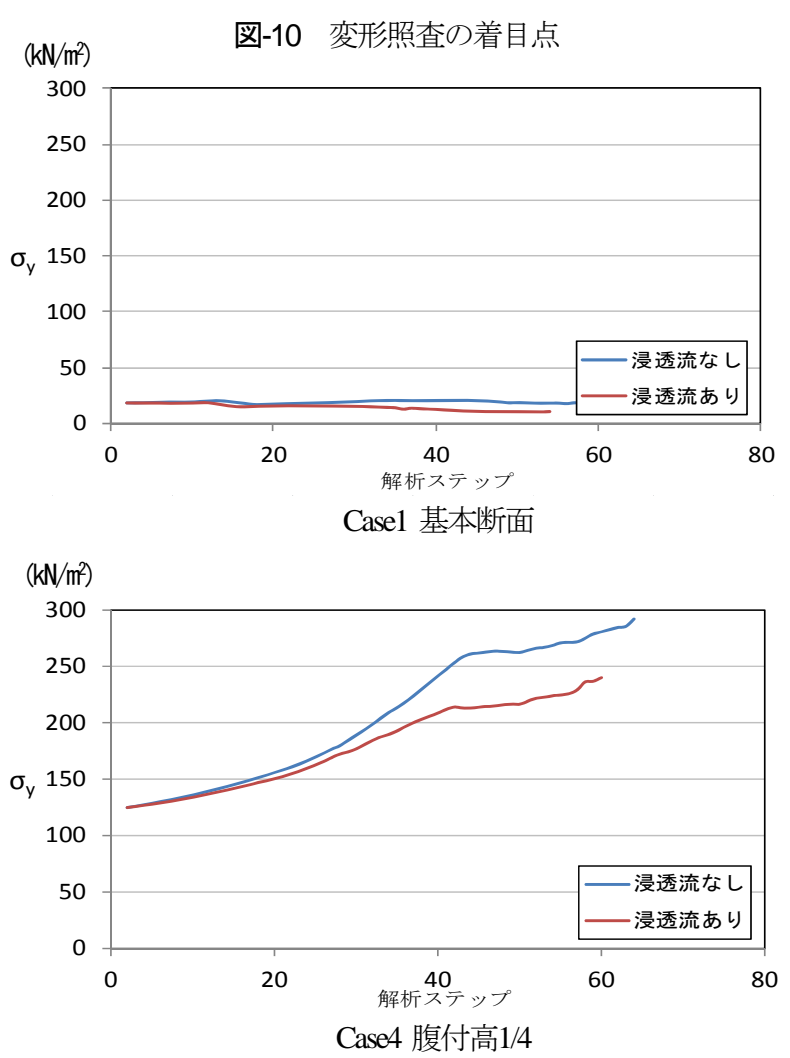

図-11 着目点における垂直応力 $\left(\sigma_{\mathrm{y}}\right)$ の変化

\section{（2）耐力作用比の比較（簡易ビショップ法とGeoFem）}

簡易ビショップ法を用いて浸透力の効果を見込んだ耐 力照査を行うことを目的に, 簡易ビショップ法と GeoFem の耐力作用比を比較した. 図-12 に簡易ビショッ プ法と GeoFem により浸透力を考慮しない場合の耐力作 用比の関係，図-13 に浸透力を考慮した場合の関係を示 す.ここで, 縦軸は GeoFem で求めた耐力作用比, 横軸 は簡易ビショップ法で求めた耐力作用比である. 検討の 結果，簡易ビショップ法と GeoFem の間にはそれぞれ高 い相関性が見られた $\left(R^{2}=0.97 ， 0.96\right)$ 。なお，簡易ビシ ヨップ法で耐力作用比を求める際の津波波力の算定には, GeoFem と同式を用いた，また，簡易ビショップ法での マウンド(港外側，港内側，ケーソン直下)の見かけの粘 着力と内部摩擦角は, 港湾基準 ${ }^{1}$ に準じて $c=20 \mathrm{kN} / \mathrm{m}^{2}, \phi$ $=35^{\circ}$ とした.

本検討では，浸透流を考慮した支持力の評価を簡易 ビショップ法により実施することを目標としている。そ のため, 簡易ビショップ法とGeoFemの関係において,

「而力作用比（簡易ビショップ法）>1.0かつ耐力作用

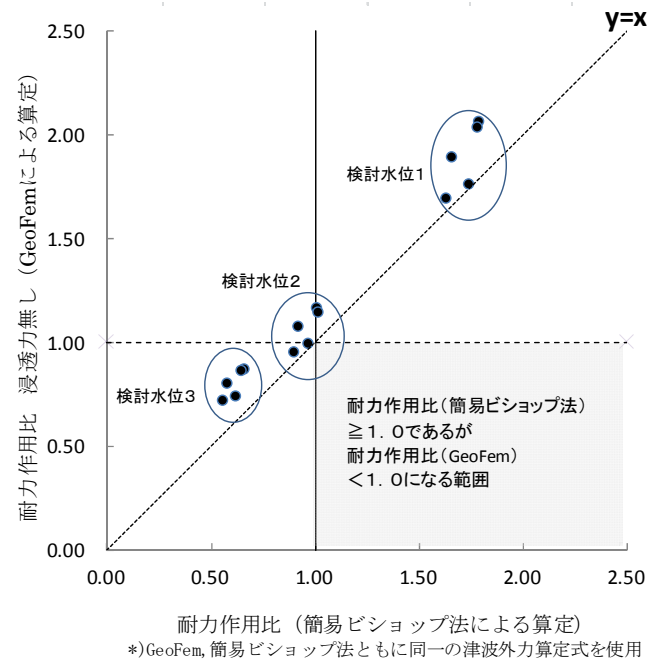

図-12 簡易ビショップ法とGeoFem（浸透力を考慮しない場合） による耐力作用比の関係

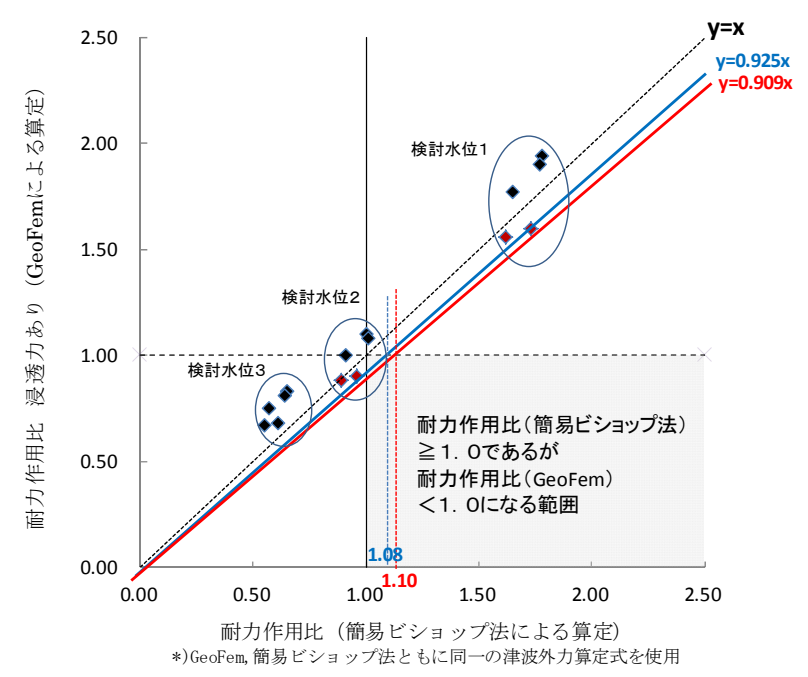

図-13 簡易ビショップ法とGeoFem（浸透力を考慮する場合） による耐力作用比の関係 
比 $(\mathrm{GeoFem})<1.0 」$ とな範囲のプロットは簡易ビシ ヨップ法を用いた照査において危険側となる.

図-12では, 全てのプロットが「耐力作用比 (GeoFem) > 耐力作用比（簡易ビショップ法）」の関 係になっていることより，他の検討水位における津波外 力においても支持力に対する安定性を満足すると推定し た.一方，図-13では，「耐力作用比（GeoFem）<耐力 作用比（簡易ビショップ法）」となるケースが4点見ら れたことより（図中の赤・），例えば検討水位2より少 し低い水位を用いて検討した場合に危険側の評価となる 可能性が残る。本検討の結果では，図-13に示す様に GeoFemの耐力作用比と簡易ビショップ法の耐力作用比 の差が最も大きいプロットを考慮して，簡易ビショップ 法がGeoFemと比較して安全側の評価となるように補正 すると両者の関係は $y=0.925 x$ となる. これは, GeoFemの 耐力作用比1.0に対応する簡易ビショップ法の耐力作用 比を 1.08 とすることで安全側の評価が可能となることを 意味する，以上を踏まえ，本検討では，簡易ビショップ 法による照査值を安全側に1.10とすることを提案する.

\section{4. おわりに}

本検討では，浸透流による防波堤基礎マウンドの支持力低 下現象に対する地盤解析汎用プログラム「GeoFem」の適 用性を検討するとともに，腹付工の設置による支持力向 上効果を検討した．また，簡易ビショップ法と GeoFem により求めた「而力作用比」の相関性を確認した。本検 討で得られた結果を以下にまとめる.

（1) 津波浸透力の影響は，浸透流を考慮した場合には， 考慮しない場合に比べて，耐力作用比が6〜 10\%低下 する結果となった.

(2) 腹付工は，腹付高さが高く，法面の厚い方が支持力 に対して効果的であることを確認した。

(3) 腹付工 $1 \mathrm{~m}^{3}$ あたりの支持力向上効果は，ケーソン後趾 付近への腹付け設置が最も有効であることがわかった. (4)簡易ビショップ法とGeoFemで求めた耐力作用比を比 較した結果，高い相関性がみられたことより，簡易ビシ
ヨップ法の結果に安全率を乗じることで，浸透力を踏ま えた検討の可能性が示唆された.

本検討では，浸透流を考慮した場合の簡易ビショップ 法による照査值として，安全側をみて1.10を提案したが， 今後, より多くのデータを蓄積し, 照査值の妥当性を検 証する必要がある.

謝辞：本検討の実施にあたり，意見を頂いた国土技術政 策総合研究所の宮田正史氏，港湾空港技術研究所の渡部 要一氏，鈴木高二朗氏，高橋英紀氏に感謝致します。ま た，GeoFemを用いた解析にあたり，協力して頂いた， 株式会社ジオデザインの橋爪秀夫氏に感謝致します。

\section{参考文献}

1) 日本港湾協会 : 港湾の施設の技術上の基準 - 同解説 （下巻），pp.572-576, 2007.

2) 小林正樹: 有限要素法による地盤の安定解析, 港湾 空港技術研究所報告, Vol.23, No.1, pp.83-101, 1984.

3) 高橋 英紀・佐々 真志・森川 嘉之・渡部 要一・高野 大樹：津波に対するケーソン式防波堤マウンドと腹 付工の安定性, 港湾空港技術研究所報告, Vol.54, No.2, pp.21-50, 2015.

4) 長野卓・大村厚夫 -及川隆・青木 伸之 : 津波に よる浸透力作用下の防波堤基礎マウンドの安定性に 関する検討, 沿岸技術研究センター論文集, No.15, pp.31-35， 2015.

5）全国漁港漁場協会 : 漁港 - 漁場の施設の設計参考図 書 2015 年版（上巻），pp.106-108， 2016.

6) 国土交通省 港湾局：防波堤の耐津波設計ガイドライ ン (一部改訂) , pp.26, 2015.

7) 沿岸技術研究センター：GeoFem（地盤解析汎用プロ グラム) マニュアル, pp.25, 1997.

8) 日本道路協会 : 道路土工 軟弱地盤対策工指針, pp.36, 1986.

9) 日本港湾協会 : 港湾の施設の技術上の基準 - 同解説 （上巻）, pp.306, 2007.

10) Takahashi, H., Sassa, S., Morikawa, Y., and Takano, D.:Bearing capacity of breakwater mound undertsunamiinduced seepage flow, Proceedings of the SixthJapan Taiwan Joint Workshop on Geotechnical Hazardsfrom Large Earthquakes and Heavy Rainfalls, 2014.

(2016.2.4受付)

\title{
ANALYSIS ON THE EFFECT OF WIDENING WORKS OF BREAKWATERS AGAINST TSUNAMI-INDUCED SEEPAGE FLOW IN THE RUBBLE MOUND
}

\author{
Masahiro SATO, Atsuo OMURA, Daisuke SHIBATA, Kotaro UEHARA , \\ Takashi OIKAWA and Nobuyuki AOKI
}

The study aims at confirming the effect of widening works for caisson type breakwaters against tsunami-induced seepage flow in the rubble mound. The study compares the calculated baring force of rubble mound by the Geotechnical Finite Element Analysis (GeoFem) and that by the Simplified Bishop Method stipulated by the Technical Standard for Port and Harbor Facilities. The result shows a strong correlation between the two. 